\title{
MARKETING DE SERVIÇOS
}

O desenvolvimento do Marketing de Serviços, ocorrido em função do crescimento do setor terciário no país, torna notória a necessidade de se discutir a produção bibliográfica gerada pela área. Esse crescimento ocorreu em função do fato do Marketing de Serviços, mais do que um caso especial de marketing, como era encarado até pouco tempo atrás, ser efetivamente diferente do marketing de produtos. Com isso, muitos cursos e bibliografias especializa- das surgiram e a área tornou-se grande fonte de inovação e desenvolvimento de práticas e conceitos, tanto na academia quanto no dia-a-dia das empresas. Nesse contexto, Ricardo Teixeira Veiga, Professor do Centro de Pós-Graduação e Pesquisa em Administração da Universidade Federal de Minas Gerais (Cepead/UFMG), faz uma seleção dos livros que podem fornecer uma visão mais abrangente da área, tanto no contexto nacional quanto no internacional.

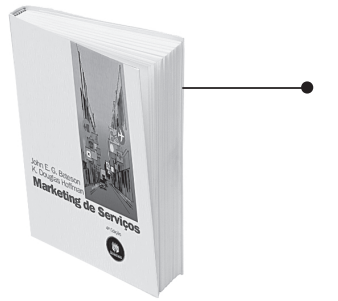

MARKETING DE SERVIÇOS John E. G. Bateson e Douglas Hoffman $4^{a}$ ed. Porto Alegre, Bookman, 2001. 495 p. O livro está dividido em três partes: a primeira apresenta os fundamentos conceituais do marketing de serviços; a segunda aborda a criação e gerenciamento da prestação de serviços; e a terceira apresenta uma visão abrangente da gestão de serviços com base em estratégias genéricas de competição. Um aspecto bastante interessante é a inclusão de artigos acadêmicos de consagrados periódicos, que ilustram os assuntos abordados e aprofundam sua discussão, a partir de evidências empíricas. O livro possibilita relacionar facilmente essa disciplina à gerência de operações e ao marketing de relacionamento.

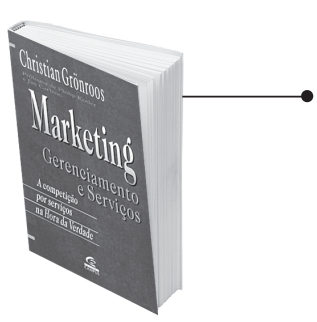

MARKETING: GERENCIAMENTO E SERVIÇOS - A competição por serviços na hora da verdade Christian Grönroos Rio de Janeiro: Campus, 1995. 377 p.

O autor busca sintetizar conhecimento científico com experiência prática nas áreas de marketing, gerenciamento, operações e comportamento organizacional, para orientar a gestão de serviços, no sentido do desenvolvimento e execução de uma estratégia de serviços orientada para o mercado. Baseando-se na perspectiva da experiência gerencial escandinava e da Escola Nórdica de Serviços, o autor incorpora também elementos da prática gerencial americana. O resultado é uma obra penetrante, cujo propósito é mais instruir sobre como pensar de forma abrangente e integrada do que

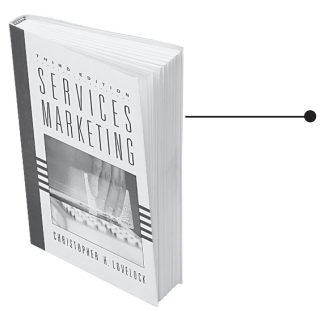
propriamente ensinar como agir.

SERVICES MARKETING Christopher H. Lovelock. $3^{\text {a }}$ ed. Upper Saddle River (NJ): Prentice-Hall, 1996. 660 p. $\mathrm{O}$ autor propõe um enfoque diferenciado para o marketing de organizações de serviços quando comparado ao marketing de empresas de manufatura, sob a forma de adaptação das metas de marketing e das estratégias correspondentes à natureza dos serviços. Dividido em quatro partes: Compreendendo serviços, Questões estratégicas em marketing de serviços, Ferramentas para profissionais de marketing de serviços e Desafios para a gerência sênior, trata-se de um excelente livro para estudiosos e profissionais de marketing de serviços.

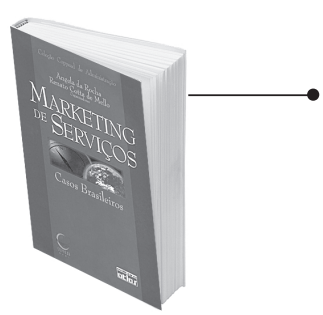

MARKETING DE SERVIÇOS: casos brasileiros Ângela da Rocha e Renato Cotta de Mello. São Paulo: Atlas, 2000. $322 \mathrm{p}$.

Os organizadores apresentam uma coletânea de casos brasileiros de marketing de serviços, escritos na década de 1990. Os autores dos casos são alunos de pós-graduação ou professores da UFRJ (Coppead). Os 18 casos do livro estão organizados em três partes: casos de varejo, casos de marketing financeiro e casos de empresas de saúde. De leitura agradável e estimulante, o livro preenche uma lacuna da falta de casos brasileiros atuais de maior profundidade sobre marketing de serviços que possam ser utilizados em cursos universitários e treinamento de executivos.

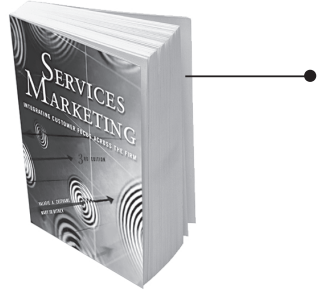

SERVICES MARKETING Valarie A. Zeithaml e Mary Jo Bitner McGraw-Hill, 1996. 700 p.

Baseando-se nas peculiaridades dos serviços, as autoras estruturam seu livro conforme as lacunas do modelo de qualidade de serviços (SERVQUAL), após abordar as especificidades do comportamento do consumidor de serviços. Desse modo, o livro aprofunda a análise das diferenças do marketing de serviços em relação ao de bens, explicando por que muitas vezes são necessárias estratégias diferentes das convencionais para enfrentar os problemas da área. Um desafio para o professor é contextualizar a discussão no Brasil atual. 